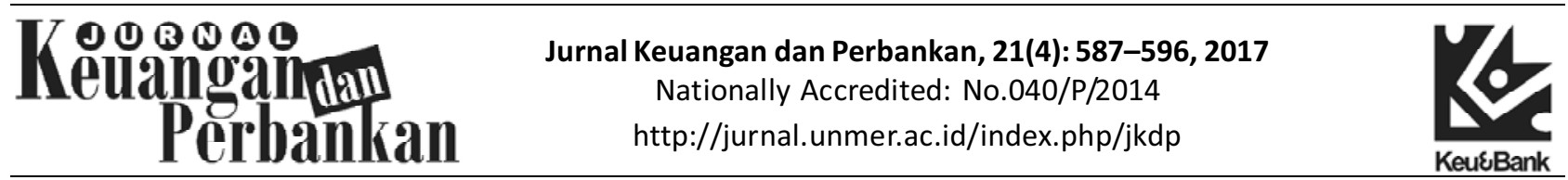

\title{
Is Investment Policy Value-Enhancing through CSR Disclosure?
}

\author{
Jaja Suteja, Annisa Nur Mayasari \\ Department of Management, Faculty of Economics and Business, Universitas Pasundan \\ Jl. Tamansari No. 6-8 Bandung, 40116, Indonesia
}

\begin{abstract}
Keywords: CSR disclosure; firm value; dividend policy; funding policy, investment policy

JEL Classification: G3, G30, G32, M14

This study aims to analysis the effect of funding policy, dividend, and investment on corporate value and the influence of corporate social responsibility (CSR) disclosure as a moderating variable in the relationship between investment policy and firm value. By using purposive sampling methods, selected sample of this research are 6 property, real estate and construction companies listed on IDX within the period of 2012-2016. Data analysis using moderated regression analysis. From this study, it has been found that funding policy has no significant effect on firm value, dividend policy has significant effect to firm value, and investment policy has significant effect to firm value. The result also signifficantly showed CSR disclosure proved to be a moderating variable of the relationship between investment policy to firm value. Disclosure of CSR should be considered as a result of the implementation of the decision. Property, real estate and construction companies should be more aware of the importance of implementing corporate social responsibility to increase corporate value. Disclosure of CSR should be considered as a result of the implementation of the decision.

\section{ABSTRAK}

Penelitian ini bertujuan untuk menganalisis pengaruh kebijakan pendanaan, dividen, dan investasi terhadap nilai perusahaan dan pengaruh pengungkapan corporate social responsibility (CSR)

Kata kunci: pengungkapan CSR; nilai perusahaan; kebijakan dividen; kebijakan pendanaan; kebijakan investasi sebagai variabel moderasi dalam hubungan antara kebijakan investasi dan nilai perusahaan. Sampel yang dipilih berjumlah 6 perusahaan properti, real estate dan konstruksi yang terdaftar di BEI periode 2012-2016 secara purposive sampling. Analisis data menggunakan moderated regression analysis. Hasil analisis kebijakan pendanaan tidak berpengaruh signifikan terhadap nilai perusahaan, kebijakan dividen berpengaruh signifikan terhadap nilai perusahaan, dan kebijakan investasi berpengaruh signifikan terhadap nilai perusahaan. Pengungkapan CSR terbukti secara signifikan sebagai variabel pemoderasi hubungan antara kebijakan investasi terhadap nilai perusahaan. Pengungkapan CSR harus dipertimbangkan sebagai akibat dari pelaksanaan keputusan tersebut. Perusahaan properti, real estate dan konstruksi harus lebih menyadari pentingnya penerapan corporate social responsibility untuk peningkatan nilai perusahaan. Pengungkapan CSR harus dipertimbangkan sebagai akibat dari pelaksanaan keputusan tersebut.
\end{abstract}




\section{Jurnal Keuangan dan Perbankan | KEUANGAN}

Vol. 21, No. 4, Oktober 2017: 587- 596

The main objective of any company is to maximize shareholder wealth by achieving maximum profit in order to pursue competitive advantage (Honggowati et al., 2017). A company must be cauitous in making decisions considering the impact that will be faced by shareholders. As a public company, every activity of the company will be monitored by the market and represent the stock price. Therefore, the main purpose of a company should be to maximize the wealth of the owner or the equivalent to maximize stock prices (Gunardi, 2010; Nohong, 2016).

A company aims to prosper its owner, in this case the shareholders, that is by increasing the value of the company (Cahyaningdyah \& Ressany, 2012). Firm value is important for the business, because it reflects the welfare of the owner. The manager, as the representative of the owner, is responsible for managing the company in order to increase the value of the company (Wardani \& Hermuningsih, 2011). Financial management is one area that can be used to increase the value of the company through financial management policies (Qureshi, 2007).

Company's value is determined by many complex factors (Hong, 2017). Earlier research obtained different conclusions about the effect of funding policies, investment, and dividends on corporate value. Some researchers (Cahyaningdyah \& Ressany, 2012; Mai, 2015; Matondang \& Yustrianthe, 2016; Sartini \& Purbawangsa, 2014; Sienatra, Sumiati, \& Andarwati, 2015; Wardoyo \& Veronica, 2013) have found that funding, dividend, and investment policies have an effect on corporate value, whilst others have found that funding, dividend, and investment policies do not have a significant impact on firm value ( Efni et al., 2012; Fallatah \& Dickins, 2012; Nisasmara \&; Pamungkas \& Puspaningsih, 2013; Yuliani, Isnurhadi, \& Bakar, 2013; Ambarwati \& Stephanus, 2014; Musdholifah, 2016). Based on the results of the research, there is a gap from the previous research (research gap) which became one of the source of the issue in this research.

The number of research being conducted on corporate social responsibility (CSR) is growing rapidly, consistent with the growing number of cases that occurred when companies does not give a positive impact to the surrounding environment. There are increasing problems of exploitation of natural resources, increasing pollution and greenhouse gas emissions and thereby damaging the SDGs (Wang, Song, \& Yao, 2013; Asmeri, Alvionita, \& Gunardi, 2017; Jones et al., 2017; Khoiruman \& Haryanto, 2017). The actions undertaken by public companies are attracting public attention, as they involve different interests from many parties, including the government, shareholders, potential investors, creditors, and the general public.

In this research, CSR disclosure is treated as moderating variable, because it can affect the influence of investment policy on firm value. Efni et al. (2012) argued from the three kinds of financial management policy, it turns out investment decisions make the most major contribution to the value of the company. This study also refers to previous research that has been done about the influence of CSR on corporate value (Choi, Kwak, \& Choe, 2010; Crisóstomo, Freire, \& Vasconcellos, 2011; Nahda \& Harjito, 2011; Tanjung, 2014; Purnamawati, Yuniarta, \& Astria, 2017; Singh, Sethuraman, \& Lam, 2017).

This research aim to analysis the influence of funding policy, dividend, and investment to firm value and the influence of CSR disclosure as a moderating variable in the relationship between investment policy and firm value.

\section{HYPOTHESES DEVELOPMENT}

\section{Funding Policy and Firm Value}

According to Sienatra, Sumiati, \& Andarwati (2015), leverage can increase the value of the company. This confirms agency theory in which agency 
theory suggests a way to avoid conflicts between managers and shareholders to increase firm value by using debt as a control.

Result of research Matondang \& Yustrianthe (2016), leverage have significant effect to firm value. Leverage shows the extent to which a company's operations are financed with debt. Excess large debt will have a negative impact on the firm value, which leads to financial distress so that to decrease the firm value.

The leverage in the study Ambarwati \& Stephanus (2014) was measured using DER and showed a significant positive effect on firm value. The positive influence of DER on the value of the company can be interpreted that the higher the value of DER then the firm value is increasing.

$\mathrm{H}_{1}$ : there is an effect of the funding policy on firm value

\section{Dividend Policy and Firm Value}

The results of the study Mai (2015) indicate that the company's ability to improve policies to improve payments greatly determines the increase in the value of Tobin's proprietary company $Q$.

According to Cahyaningdyah \& Ressany (2012), the dividend policy proportioned by using the dividend payout ratio has a positive influence on the value of the company, as the greater the dividend distributed will affect the investors, thus generating positive sentiments or good assumptions about the company become the place of investment. Dividend policy is one factor that maximizes the value of the firm, because of its strong influence on the market price of the outstanding shares. Therefore, managers in this case are required to distribute dividends as a realization of the expected outcomes coveted by an investor.

Sienatra, Sumiati, \& Andarwati (2015), also revealed that dividends are also factors that can increase the value of the company This is due to dividend is a picture of the prospects of the com- pany in the future so that a dividend distribution gives cues about the condition of the company at this time that the company's performance both and indirectly will create a perception in both investors and reflected from the stock price that increases the firm value.

$\mathrm{H}_{2}:$ there is an effect of the dividend policy on firm value

\section{Investment Policy and Firm Value}

Return on Equity (ROE) and Return on Assets (ROA) is an example of an important indicator that is often used by investors to assess the level of profitability of the company before investing. Other research on factors affecting firm value is done by Cahyaningdyah \& Ressany (2012).

One of the main reasons companies operate is generating profits that are beneficial to shareholders. The measure of the success of achieving these reasons is that the greater ROE and ROA reflect the company's ability to generate high returns for shareholders. This has an impact on the increase of firm value. For the effect of financial performance on firm value.

Research Pamungkas \& Puspaningsih (2013), investment decisions have a significant effect on the value of the firm. With the investment, investors assume that in the future the profitability of the company will increase. Thus investors will be more interested in buying shares of companies that make investments, so this will result in stock prices will increase, which will ultimately increase the firm value.

Based on the research Yuliani, Isnurhadi, \& Bakar (2013), the results of analysis of the influence of investment decisions on firm value showed significant results. It is understood that the higher investment decisions affect the increase in firm value.

$\mathrm{H}_{3}$ : there is an effect of the investment policy on firm value 


\section{Jurnal Keuangan dan Perbankan | KEUANGAN}

Vol. 21, No. 4, Oktober 2017: 587- 596

\section{CSR Disclosure and the Relationship between Investment Policy and Firm Value}

According to Asmeri, Alvionita, \& Gunardi (2017), CSR is a form of environmental and social entity concern that is integrated into its operations and its interaction with stakeholders.

The research conducted by Choi, Kwak, \& Choe (2010), looking at the effect of the relationship between CSR and the company's financial performance, the indicators for the performance used are ROE, ROA and Tobin's Q. The result of study there is a positive and significant relationship between the financial performance of the company and CSR index.

The results of research Nahda \& Harjito (2011), show that CSR significantly positive effect on the firm value. This means that the better the implementation of CSR by the company then the firm value will increase.

$\mathrm{H}_{4}$ : CSR disclosure is able to moderate the influence of investment policy on firm value

\section{METHODS}

The method used in this research, that is descriptive and verification method. Population used in this research is property, real estate, and construction companies that are listed in Indonesia Stock Exchange (IDX) period 2012-2016. The data used is obtained from the IDX website. The total population in the study of 59 companies, a certain number will be chosen as a sample.

In this study, the sample is determined by using purposive sampling method (Rahmawati et al., 2017). The sampling method limits the selection of samples based on a certain criteria. The company criteria sampled in this study are: (1) companies included in the property, real estate, and construction groups listed on the IDX and published the financial statements and annual reports from 2012-2016. (2) Property, real estate, and construction companies that distributed cash dividends for five consecutive years from 2012-2016. (3) Property, real estate, and construction corporation that discloses CSR in its annual report consecutively during 2012-2016. (4) Property, real estate and construction companies that have a complete data required in this study.

Based on the criteria that have been set, companies that meet the requirements as a research sample that is amounted to 6 (six) companies. Selection of these companies is aiming to find out whether the property, real estate and construction companies listed on the IDX are able to create a good corporate value in line with the growing interest on investment on that specific sectors.

The dependent variable on the research, which is the firm value is proxied by Tobin's $Q$ and the independent variable, the funding policy is proxied by Debt to Equity Ratio (DER), dividend policy is proxied by Dividend Payout Ratio (DPR), investment policy using Return on Assets (ROA) and Return on Equity (ROE), while moderating variables use disclosure CSR.

The classical assumption measurements used in this study include normality test, multicollinearity test, heteroscedasticity test, and autocorrelation test. In this study, test the regression with moderating variables, namely by interaction test. Interaction test or often called Moderated Regression Analysis (MRA). The regression equation models for this study are as follows.

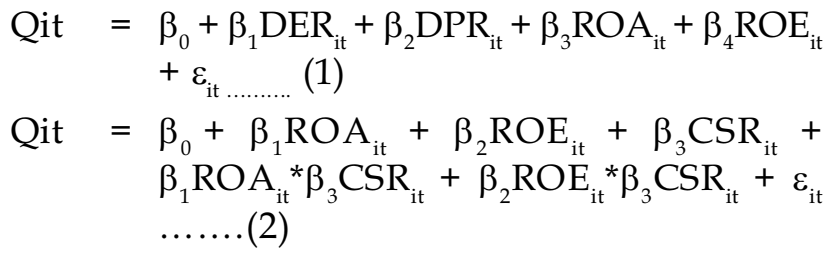

Qit $=\beta_{0}+\beta_{1} \mathrm{ROA}_{\mathrm{it}}+\beta_{2} \mathrm{ROE}_{\mathrm{it}}+\beta_{3} \mathrm{CSR}_{\mathrm{it}}+$ $\beta_{1} \operatorname{ROA}_{\mathrm{it}}{ }^{*} \beta_{3} \mathrm{CSR}_{\mathrm{it}}+\beta_{2} \mathrm{ROE}_{\mathrm{it}}{ }^{*} \beta_{3} \mathrm{CSR}_{\mathrm{it}}+\varepsilon_{\mathrm{it}}$ (2)

Note:

Q

: Tobin's Q

DER : Debt to Equity Ratio

DPR : Dividend Payout Ratio 


$\begin{array}{ll}\text { ROA } & : \text { Return on Assets } \\ \text { ROE } & : \text { Return on Equity } \\ \text { CSR } & : \text { CSR disclosure } \\ \text { ROA }^{*} \text { CSR } & : \text { the interaction of return on assets } \\ & \text { with CSR disclosure, measured by } \\ & \text { the multiplication of ROA and CSR } \\ \text { ROE }^{*} \text { CSR } & : \text { the interaction of return on equity } \\ & \text { with CSR disclosure, measured by } \\ & \text { multiplication of ROE and CSR } \\ \beta_{0} & : \text { constants } \\ \beta_{1}, \ldots \beta_{4} & : \text { regression coefficient } \\ \mathrm{e} & : \text { error }\end{array}$

\section{RESULTS}

Descriptive statistical output of six samples of companies of Real Estate and Construction companies listed in IDX for the period 2012-2016 are shown in Table 1.
Table 1. Descriptive Statistics Independent, Dependent, and Moderation Variables

\begin{tabular}{llcc}
\hline \multicolumn{1}{c}{ Variable } & $\mathbf{N}$ & Mean & Std. Deviation \\
\hline Tobin's Q & 30 & 1.0057 & 0.97652 \\
DER & 30 & 1.8071 & 1.20491 \\
DPR & 30 & 0.4869 & 0.85500 \\
ROA & 30 & 0.0677 & 0.03314 \\
ROE & 30 & 0.1877 & 0.08950 \\
CSR & 30 & 0.4803 & 0.26884 \\
ROA $^{*}$ CSR & 30 & 0.0311 & 0.02879 \\
ROE $^{*}$ CSR & 30 & 0.0906 & 0.07526 \\
\hline
\end{tabular}

Based on Table 1, the number of data used in this study is 30 which is the result of multiplication between the company into the sample (6 companies) with the research period (5 years). The average in Table 1 is the average of all the data for each variable, whereas the standard deviation is the amount of data deviation from the average data that has been entered. The larger the standard deviation of a variable means the larger the range width of the data has been entered. The smaller the standard deviation of a variable means the narrower the range of data that has been entered.

Table 2. Summary of Classic Assumption Test Results

\begin{tabular}{|c|c|c|}
\hline \multirow{2}{*}{$\begin{array}{c}\text { Classical } \\
\text { Assumption Test }\end{array}$} & \multicolumn{2}{|c|}{ Equation } \\
\hline & 1 & 2 \\
\hline Normality & $\begin{array}{l}\text { Provides a normal approximation of normal } \\
\text { distribution patterns and indicates that the data } \\
\text { spreads around the diagonal line and follows the } \\
\text { diagonal direction }\end{array}$ & $\begin{array}{l}\text { Provides a normal approximation of normal } \\
\text { distribution patterns and indicates that the } \\
\text { data spreads around the diagonal line and } \\
\text { follows the diagonal direction }\end{array}$ \\
\hline Multikolinearitas & $\begin{array}{l}\text { Tolerance Value: DER is } 0.612 \text {. House of } \\
\text { Representatives is } 0802 \text {. ROA is } 0.282 \text {. ROE is } \\
0.244 \text {. The VIF DER value is } 1,633 \text {. The House of } \\
\text { Representatives is } 1,246 \text {. ROA is } 3,549 \text {. ROE is } \\
4,103 \text {. Based on Tolerance and Variance Inflation } \\
\text { Factor (VIF) it can be concluded that in this } \\
\text { research there is no multicolinearity which } \\
\text { means there is no relationship between } \\
\text { independent variables in the regression model. }\end{array}$ & $\begin{array}{l}\text { there are symptoms of multicolinearity in the } \\
\text { regression model used. This is because there } \\
\text { is an element of moderation. Furthermore, } \\
\text { improvements are made by transforming into } \\
\text { the Ln form on independent variables and } \\
\text { moderation. So there are no symptoms of } \\
\text { multicolinearity. }\end{array}$ \\
\hline Heteroscedasticity & $\begin{array}{l}\text { Plot spread, thus it can be concluded that there is } \\
\text { no symptoms of heteroscedasticity on the } \\
\text { regression model. }\end{array}$ & $\begin{array}{l}\text { Plot spread, thus it can be concluded that } \\
\text { there is no symptoms of heteroscedasticity on } \\
\text { the regression model. }\end{array}$ \\
\hline Autocorrelation & $\begin{array}{l}\text { The } \mathrm{D}-\mathrm{W} \text { value }(1,032) \text { is at the criteria of no } \\
\text { autocorrelation. }\end{array}$ & $\begin{array}{l}\text { The } \mathrm{D}-\mathrm{W} \text { value }(1.120) \text { is on the criteria of no } \\
\text { autocorrelation. }\end{array}$ \\
\hline
\end{tabular}




\section{Jurnal Keuangan dan Perbankan | KEUANGAN}

Vol. 21, No. 4, Oktober 2017: 587- 596

The results of the classic assumption test show results that there is no serious problem. The models in this study did not experience symptoms of normality, multicollinearity, heteroscedasticity, and autocorrelation (See Table 2).

The value of R-Square in model 1 is 0.386 . This means that $38.6 \%$ of firm value may be affected by funding, dividend and investment policies, while the remaining $61.4 \%$ may be affected by other variables not included in this research model.

\section{DISCUSSION}

Result of hypotheses test show that funding policy have a significantly positive effect to firm value not proven. The results of this study indicate that DER does not affect the value of the company. DER that does not affect the value of this company, which is not supporting the research hypotheses stating that funding decisions have a significant effect on the value of the company.

The results of this study strengthen the study by Wardani \& Hermuningsih (2011); Efni et al. (2012); Yuliani, Isnurhadi, \& Bakar (2013); Wiagustini \& Pertamawati (2015) to explain why hypotheses testing affect the funding decision on firm value is not proven. The increased use of debt to some extent increases the firm value. Passing that limit, the use of debt will reduce the value of the company because the benefits of debt (tax savings) is smaller than the costs incurred due to the debt in the form of agency fees and debt interest costs. If the company is not able to finance these two costs will cause financial distress so that the value of the company decreases ( Matondang \& Yustrianthe, 2016; Suteja, Gunardi, \& Octavia, 2017)

It is also possible because in the Indonesian capital market the movement of stock prices and the creation of value adding of the company is due to market psychological factors. The investors is not too concerned about the amount of debt owned by the company, because investors are focus on looking at how the company's management use the funds effectively and efficiently to achieve added value for the company. Thus the value of the company is not affected even though the funding decision is changed. The results of this study are in line with the study (Pamungkas \& Puspaningsih, 2013).

Table 3. Results from Moderated Regression Analysis

\begin{tabular}{|c|c|c|c|c|c|c|}
\hline \multirow{2}{*}{ Variable } & \multicolumn{3}{|c|}{ Model 1} & \multicolumn{3}{|c|}{ Model 2} \\
\hline & Coefficient & t-statistics & Sig. & Coefficient & t-statistics & Sig. \\
\hline Intercept & 0.191 & 0.398 & 0.694 & 1.646 & 2.038 & 0.053 \\
\hline DER & 0.089 & 0.547 & 0.589 & & & \\
\hline DPR & 0.421 & 2.105 & $0.046^{* *}$ & & & \\
\hline ROA & 22.909 & 2.960 & $0.007^{*}$ & 52.602 & 4.001 & $0.001^{*}$ \\
\hline ROE & -5.381 & -1.553 & 0.133 & -19.687 & -3.489 & $0.002^{*}$ \\
\hline CSR & & & & -1.623 & -1.160 & 0.257 \\
\hline $\mathrm{ROA}^{*} \mathrm{CSR}$ & & & & -78.604 & -2.673 & $0.013^{* *}$ \\
\hline $\mathrm{ROE}^{*} \mathrm{CSR}$ & & & & 32.282 & 2.746 & $0.011^{* *}$ \\
\hline $\mathrm{R}$ & & 0.621 & & & 0.710 & \\
\hline $\mathrm{R}^{2}$ & & 0.386 & & & 0.503 & \\
\hline F-statistics & & 3.927 & & & 4.866 & \\
\hline Sig. & & $0.013^{* *}$ & & & $0.003^{*}$ & \\
\hline Dependen: & & & & & & \\
\hline Tobin's Q & & & & & & \\
\hline
\end{tabular}

*Significant at the 0.01 level, ${ }^{* *}$ Significant at the 0.05 level 
The result of hypotheses test shows that dividend policy has significant effect to firm value and has a positive relationship. This means that the higher cash dividend payout of a company will generate a positive signal for shareholders and cause an increase in the company's stock price and impact on the increase of corporate value (Sartini \& Purbawangsa, 2014). This positive impression will be responded by the market with rising stock prices which also means increasing the value of the company.

The influence of a positive dividend policy on corporate value is in line with the research by Cahyaningdyah \& Ressany (2012), Mai (2015), Sartini \& Purbawangsa (2014) because the greater the dividend distributed will affect the investors, so it will generate a positive sentiment or good assumption about the company they will put their money on. Dividend policy is among one factors that maximizes the value of the firm, because of its strong influence on the market price of the outstanding shares. Therefore, managers in this case are required to distribute dividends as a realization of the expected outcomes coveted by an investor. Thus, the ability of firms in improving policies to increase dividend payouts greatly determines the increase in corporate value. This supports the research by (Sienatra, Sumiati, \& Andarwati, 2015) where dividends represent the future prospects of the company and provide cues about the current state of the company that the company has a good performance.

Hypotheses test results indicate that investment policy measured by ROA has a significantly positive effect on firm value. The greater the ROA will increase the firm value, the smaller the ROA, the lower the corporate value. This is because high profits will provide an indication of good corporate prospects that can trigger investors to increase share demand. Increased stock demand will lead to increased corporate value.
The results of this study adds up to the results of research by Efni et al. (2012), Wardoyo \& Veronica (2013), Matondang \& Yustrianthe (2016) investment decisions by property and real estate companies in the form of return on assets can increase the value of the company. The value of the firm is determined by earnings power of the firm's assets. The higher earnings power the more efficient the asset turnover and or the higher the proft margin obtained by the company. This certainly affects the increase in corporate value because the better the performance of a company, the higher the value of the company

The result of hypotheses test shows that investment policy measured by ROE has no significant effect to firm value and has negative relation. The size of the ROE does not affect the value of the company. This study is in line with Nisasmara \& Musdholifah (2016) that a company with a small ROE does not mean that Tobins' $Q$ is so low. This shows that investors do not consider the size of the company's ROE when investing.

The R-Square value in model 2, after the inclusion of CSR as a moderating variable increased to 0.503 or $50.3 \%$. The increasing of R-Square value in this research indicates that CSR is able to moderate the relation of investment policy with firm value.

The result of hypotheses test shows that ROA have significant influence to firm value with CSR as moderation variable and have negative relation, while ROE have significant influence to firm value with CSR as moderation variable and have positive relationship.

This shows that the higher the value of ROE the higher the value of the company, especially with the disclosure of CSR which aims to increase investor confidence in investing capital because investors assume that the company will continue to grow and the public will support the companies whose profits will be set aside for the sake of 


\section{Jurnal Keuangan dan Perbankan | KEUANGAN}

Vol. 21, No. 4, Oktober 2017: 587- 596

social and environmental. This will build a good image in the eyes of the stakeholders and will also increase the company's profit.

These results support the results of the study by Tanjung (2014) that CSR is proven significantly as a moderating variable of the relationship between ROE and firm value. This means, in addition to seeing the financial performance reflected in the financial statements, investors also provide a positive response to companies that disclose information about its social responsibility. Asmeri, Alvionita, \& Gunardi (2017) mentioned that Corporate Social Responsibility is a form of environmental and social entity concern that is integrated into its operations and its interaction with stakeholders.

The inclusion of CSR disclosure is able to significantly moderate the influence of investment policies on corporate value. Disclosure of CSR can increase the value of the company at the time of high investment policy and CSR disclosure can reduce the value of the company at the time of low investment policy. This reinforces the results of research conducted by Choi, Kwak, \& Choe (2010), that observed the effect of the relationship between CSR, ROE, ROA and Tobin's Q.

Property, real estate and construction companies should be more aware of the importance of implementing corporate social responsibility to increase corporate value. Disclosure of CSR should be considered as a result of the implementation of the decision.

\section{CONCLUSION AND SUGGESTIONS}

\section{Conclusion}

The funding policy is unable to increase the value of companies in property and real estate companies. Increased corporate value is largely determined by the company's ability to improve its policy to increase dividend payout and invest- ment policy. CSR disclosure is significantly proven as a moderating variable of the relationship between investment policy to firm value.

\section{Suggestions}

Based on the test results, discussion, and conclusions, the following suggestions can be put forward: (1) For managers, to improve the value of the company, the managers should pay a close attention and improve the dividend payout policy and investment policy. (2) For investors, the best option for investing should be to a profitable company and ones that have the capability to increase its dividend payout, as well as a company capable of disclosing information about its social responsibilities. (3) Subsequent research should include macroeconomic factors such as interest rates, inflation rate, currency exchange rate and economic political situation can be used as information to invest. (4) For the next researcher, it would be better if in their researches to increase the number of research samples, longer periods, and this research should be further developed to further involve other sectors that have different characteristics, thus providing better and more generalized view.

\section{REFERENCES}

Ambarwati, I. E., \& Stephanus, D. S. (2014). Struktur kepemilikan, kebijakan dividen, dan leverage sebagai determinan atas nilai perusahaan. Jurnal Akuntansi Multiparadigma, 5(2), 170-184.

Asmeri, R., Alvionita, T., \& Gunardi, A. (2017). CSR disclosures in the mining industry: empirical evidence from listed mining firms in indonesia. Indonesian Journal of Sustainability Accounting and Management, 1(1), 16-22. http://doi.org/10.28992/ ijsam.v1i1.23.

Cahyaningdyah, D., \& Ressany, Y. D. (2012). Pengaruh kebijakan manajemen keuangan terhadap nilai perusahaan. Jurnal Dinamika Manajemen, 3(1), 2028. 


\title{
Is Investment Policy Value-Enhancing through CSR Disclosure?
}

\author{
Jaja Suteja \& Annisa Nur Mayasari
}

Choi, J.-S., Kwak, Y.-M., \& Choe, C. (2010). Corporate social responsibility and corporate financial performance: Evidence from Korea. Australian Journal of Management, 35(3), 291-311. http://doi.org/ $10.1177 / 0312896210384681$.

Crisóstomo, V. L., Freire, F. de S., \& Vasconcellos, F. C. de. (2011). Corporate social responsibility, firm value and financial performance in Brazil. Social Responsibility Journal, 7(2), 295-309. http://doi.org/ $10.1108 / 17471111111141549$.

Efni, Y., Hadiwidjojo, D., Salim, U., \& Rahayu, M. (2012). Keputusan investasi, keputusan pendanaan dan kebijakan dividen: pengaruhnya terhadap nilai perusahaan (Studi pada sektor properti dan real estate di Bursa Efek Indonesia). Jurnal Aplikasi Manajemen, 10(1), 128-141.

Fallatah, Y., \& Dickins, D. (2012). Corporate governance and firm performance and value in Saudi Arabia. African Journal of Business Management, 6(36), 10025-10034. http://doi.org/10.5897/ AJBM12.008.

Gunardi, A. (2010). Perubahan kinerja keuangan terhadap perubahan harga saham pada perusahaan food and beverages. Jurnal Riset Bisnis Dan Manajemen, 3(1), 11-20.

Hong, S. (2017). The effect of debt choice on firm value. Journal of Applied Business Research, 33(1), 135-140. http://doi.org/10.19030/jabr.v33i1.9874.

Honggowati, S., Rahmawati, R., Aryani, Y. A., \& Probohudono, A. N. (2017). Corporate governance and strategic management accounting disclosure. Indonesian Journal of Sustainability Accounting and Management, 1(1), 23-30. http://doi.org/ 10.28992/ijsam.v1i1.24

Jones, P., Wynn, M., Hillier, D., \& Comfort, D. (2017). The sustainable development goals and information and communication technologies. Indonesian Journal of Sustainability Accounting and Management, 1(1), 1-15. http://doi.org/10.28992/ijsam.v1i1.22.

Khoiruman, M., \& Haryanto, A. T. (2017). Green purchasing behavior analysis of government policy about paid plastic bags. Indonesian Journal of Sustainability Accounting and Management, 1(1), 31-39. http:// doi.org/10.28992/ijsam.v1i1.25.

Mai, M. U. (2015). Corporate governance dan interdependensi antara leverage, profitabilitas, serta kebijakan dividen dalam mencapai nilai perusahaan. Jurnal Keuangan dan Perbankan, 19(2), 213-225.

Matondang, J. L., \& Yustrianthe, R. H. (2016). Analisis empiris faktor yang memengaruhi nilai perusahaan high profile di Indonesia. Jurnal Akuntansi, 20(1), 134-149.

Nahda, K., \& Harjito, D. A. (2011). Pengaruh corporate social responsibility terhadap nilai perusahaan dengan corporate governance sebagai variabel moderasi. Jurnal Siasat Bisnis, 15(1), 1-12.

Nisasmara, P. W., \& Musdholifah, M. (2016). Cash holding, good corporate governance and firm value. Jurnal Dinamika Manajemen, 7(2), 117-128.

Nohong, M. (2016). Inovasi, pertumbuhan, ukuran dan nilai perusahaan farmasi di Indonesia. Jurnal Keuangan dan Perbankan, 20(2), 176-185.

Pamungkas, H. S., \& Puspaningsih, A. (2013). Pengaruh keputusan investasi, keputusan pendanaan, kebijakan dividen dan ukuran perusahaan terhadap nilai perusahaan. Jurnal Akuntansi dan Auditing Indonesia, 17(2), 156-165.

Purnamawati, I. G. A., Yuniarta, G. A., \& Astria, P. R. (2017). Good corporate governance dan pengaruhnya terhadap nilai perusahaan melalui corporate social responsibility disclosure. Jurnal Keuangan dan Perbankan, 21(2), 276-286.

Qureshi, M. A. (2007). System dynamics modelling of firm value. Journal of Modelling in Management, 2(1), 2439. http://doi.org/10.1108/17465660710733031.

Rahmawati, R., Rispantyo, R., \& Djamaluddin, S. (2017). Mentoring function and quality of supervisor auditor relationship: organizational justice as a mediation. Indonesian Journal of Sustainability Accounting and Management, 1(1), 40-48. http://doi.org/ 10.28992/ijsam.v1i1.26.

Sartini, L. P. N., \& Purbawangsa, I. B. A. (2014). Pengaruh keputusan investasi, kebijakan dividen, serta keputusan pendanaan terhadap nilai perusahaan manufaktur di Bursa Efek Indonesia. Matrik: Jurnal Manajemen, Strategi Bisnis Dan Kewirausahaan, 8(2), 81-90.

Sienatra, K. B., Sumiati, S., \& Andarwati, A. (2015). Struktur kepemilikan sebagai determinan nilai perusahaan. Jurnal Akuntansi Multiparadigma, 6(1), 124-132. 


\section{Jurnal Keuangan dan Perbankan | KEUANGAN}

Vol. 21, No. 4, Oktober 2017: 587- 596

Singh, P. J., Sethuraman, K., \& Lam, J. Y. (2017). Impact of corporate social responsibility dimensions on firm value: some evidence from Hong Kong and China. Sustainability, 9(9), 1532. http://doi.org/10.3390/ su9091532.

Suteja, J., Gunardi, A., \& Octavia, R. A. (2017). Predicting the financial distress of Indonesian manufacturing companies: an application of the multinomial logit model. International Journal of Monetary Economics and Finance, 10(3/4), 250-256. http:// doi.org/10.1504/IJMEF.2017.10008398.

Tanjung, P. R. S. (2014). Analisis pengaruh economic value added dan faktor fundamental perusahaan lainnya terhadap return saham dengan corporate social responsibility sebagai variabel pemoderasi. Mix: Jurnal Ilmiah Manajemen, 4(2), 227-248.

Wang, J., Song, L., \& Yao, S. (2013). The Determinants of corporate social responsibility disclosure: evidence from China. Journal of Applied Business Research, 29(6), 1833-1848. http://doi.org/ 10.19030/jabr.v29i6.8220.
Wardani, D. K., \& Hermuningsih, S. (2011). Pengaruh struktur kepemilikan terhadap nilai perusahaan dengan kinerja keuangan dan kebijakan hutang sebagai variabel intervening. Jurnal Siasat Bisnis, 15(1), 27-36.

Wardoyo, W., \& Veronica, T. M. (2013). Pengaruh good corporte governance, corporte social responsibility dan kinerja keuangan terhadap nilai perusahaan. Jurnal Dinamika Manajemen, 4(2), 132149.

Wiagustini, N. L. P., \& Pertamawati, N. P. (2015). Pengaruh risiko bisnis dan ukuran perusahaan pada struktur modal dan nilai perusahaan pada perusahaan farmasi di Bursa Efek Indonesia. Matrik: Jurnal Manajemen, Strategi Bisnis Dan Kewirausahaan, 9(2), 112-122.

Yuliani, Y., Isnurhadi, I., \& Bakar, S. W. (2013). Keputusan investasi, pendanaan, dan dividen terhadap nilai perusahaan dengan risiko bisnis sebagai variabel mediasi. Jurnal Keuangan dan Perbankan, 17(3), 362375 . 